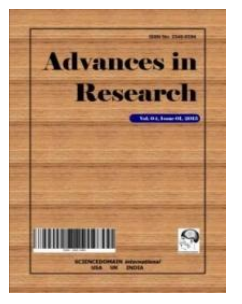

\title{
Quantification of Activity Concentrations and Radiation Hazard Indices in the Solid Minerals Exploration Fields of Benue State, Nigeria with Multivariate Statistical Approach
}

\author{
A. I. Olanrewaju ${ }^{1 *}$ and G. O. Avwiri ${ }^{1}$ \\ ${ }^{1}$ Environmental and Radiation Physics Research Group, Department of Physics, \\ University of Port Harcourt, Rivers State, Nigeria.
}

Authors' contributions

This work was carried out in collaboration between both authors. Authors AIO and GOA designed the study. Author AIO performed the statistical analysis, wrote the protocol and the first draft of the manuscript. Author GOA supervised and managed the analyses of the study. Both authors read and approved the final manuscript.

Article Information

DOI: $10.9734 / \mathrm{AIR} / 2017 / 33432$

Editor(s):

(1) Kerim R. Allakhverdiev, Azerbaijan National Aviation Academy (ANAA), Bina, 25th km, Baku, 1045, Azerbaijan and Turkish Scientific and Technological Research, Centre (TUBITAK), Marmarar Research Centre (MRC), Materials Institute, Turkey.

Reviewers:

(1) Isaac Hyuk Daniel, Kaduna State University, Nigeria

(2) Mahmut Dogru, University of Firat, Turkey. Complete Peer review History: http://www.sciencedomain.org/review-history/19360

Original Research Article

Received 15 ${ }^{\text {th }}$ April 2017

Accepted $23^{\text {rd }}$ May 2017

Published 6 ${ }^{\text {th }}$ June 2017

\begin{abstract}
The quantification of activity concentrations of radionuclides and the radiation hazard indices in the exploration fields of Benue State have been carried out. Samples of the environmental matrix (soil and minerals) were collected from five mining sites of barite, limestone, lead, coal and salt in Lessle, Gboko, Anyin, Owukpa and Akuana communities. The concentrations of radioactivity was analyzed using Nal (TI) Y-ray spectroscopy. Results showed that the concentrations of activity of the primordial radionuclides ${ }^{40} \mathrm{~K},{ }^{238} \mathrm{U}$, and ${ }^{232} \mathrm{Th}$ for soil samples obtained ranged from 11.42 (Salt) 1491.47 (Lead) Bq/kg, 12.87 (Barite) - 452.32 (Coal) Bq/kg and 6.78 (Coal)-108.41 (Barite) Bq/kg respectively. The mean value activity concentration of the radionuclides in the minerals samples at the mining sites were $10.58-623.36 \mathrm{~Bq} / \mathrm{kg}, 1.97-540.33 \mathrm{~Bq} / \mathrm{kg}$ and $2.13-25.28 \mathrm{~Bq} / \mathrm{kg}$ for ${ }^{40} \mathrm{~K}$, ${ }^{238} \mathrm{U}$, and ${ }^{232}$ Th respectively. The radium equivalent activity $\left(R a_{e q}\right)$, external hazard index, $H_{e x}$,
\end{abstract}


internal hazard index $\left(\mathrm{H}_{\mathrm{in}}\right)$, representative index $\left(\mathrm{I}_{\gamma}\right)$ and excess lifetime cancer risk calculated for soil and minerals samples compared favourably with the precautionary limits set by UNSCEAR. The excess lifetime cancer risk estimated for soil which was fairly insignificant compared with 0.05 prescribed by ICRP for low level radiation. The multivariate statistical (Pearson's correlation and cluster) analysis showed some positive significant among ${ }^{40} \mathrm{~K},{ }^{238} \mathrm{U}$ and ${ }^{232} \mathrm{Th}$, and with other radiological parameters in some mine fields. The study indicated that the minerals and soil samples from the mining sites will pose no major health risk to the public if used for industrial activities except for the salt minerals consumption.

Keywords: Absorbed dose; activity concentration; hazard index; radionuclides.

\section{INTRODUCTION}

Mineralised zone is marked by the presence of elevated levels of certain minerals, which are associated with heavy metals and/ or radionuclides. The extent and nature of mineralisation is highly dependent on the geological setting of the area. High mineral prices and demand have stimulated an investment surge in mineral exploration and production in particularly the developing countries [1]. Nigeria has a long, but discontinuous history of mining and the country was a prominent exporter [2].

The need to diversify the economy from mono product has led to increased activities in non-oil exploration of solid minerals. The capacity of mineral based exploration activities have increased, concern on adverse effects of the exploring minerals exposure to man and society have required great emphasis.

Mining and processing of mineral rocks can redistribute and concentrate the radionuclides in the environment, which can in turn enhance the environmental radiation levels above normal background [3]. The natural radioactivity concentration of raw minerals depends on their mineralogy and geochemistry, and a few raw minerals are occasionally found to have comparatively high concentrations of natural radioactivity [3]. Furthermore, the composition of each lithological separated area and the specific levels of terrestrial environmental radiations are related, and also to the content of the rock from which the soils originate [4]. Therefore, radiation levels knowledge and basic radiological parameters in materials is vital to assess possible radiological risk to human health.

\section{MATERIALS AND METHODS}

\subsection{Study Area}

The study areas are located in Benue State which lies within the lower river Benue trough in the middle belt region of Nigeria and are within the geographical points situated on longitude $7^{\circ}$ $47^{\prime}$ and $10^{\circ} 0$ ' East and Latitude $6^{\circ} 25^{\prime}$ and $8^{\circ} 8^{\prime}$ North. The geology of the study area is principally of sedimentary formation with pockets of basement complex which is made up of sandstones, mudstones and limestone that influences both surface and ground water availability $[5,6]$. Benue State is endowed with solid mineral resources such as industrial minerals - barites, kaolin, gypsum, limestone; Energy mineral - coal, Chemical mineral - brine; Metallic mineral - wolframite, bentonite clay, lead and zinc etc, which are evenly distributed over the existing geographical location, some of which are not yet being mined but are being investigated [7]. Fig. 1 shows the location map of the study area.

\subsection{Sample Collection and Preparation}

Five major mining sites from which the raw minerals, barite, limestone, lead, coal and salt are obtained in Benue state. At each site two (2) samples of the type of mineral mined were collected. Also about 6 soil samples were collected at different locations around the mining area. The soil samples were collected to a depth of $150 \mathrm{~mm}$ at each site. A total of ten (10) mineral samples and thirty (30) soil samples were collected around the mining areas.

The soil samples for gamma analysis were dried, pulverized, sieved and thoroughly homogenized by a $2 \mathrm{~mm}$ mesh to remove larger objects. Samples of about $500 \mathrm{~g}$ each were packed in marinelli beaker of about $500 \mathrm{~cm}^{3}$ volume and sealed using silicon and plastic tapes for air tight to prevent escape of radon. The samples were left for a minimum period of four weeks for radioactive secular equilibrium between ${ }^{222} R n$ radon gas and its decay products $\left({ }^{214} \mathrm{~Pb},{ }^{214} \mathrm{~B}\right.$ and ${ }^{226} R a$ ), from the ${ }^{238} U$ decay series to be acquired [8]. Each of the sealed samples after attaining secular equilibrium were later subjected 


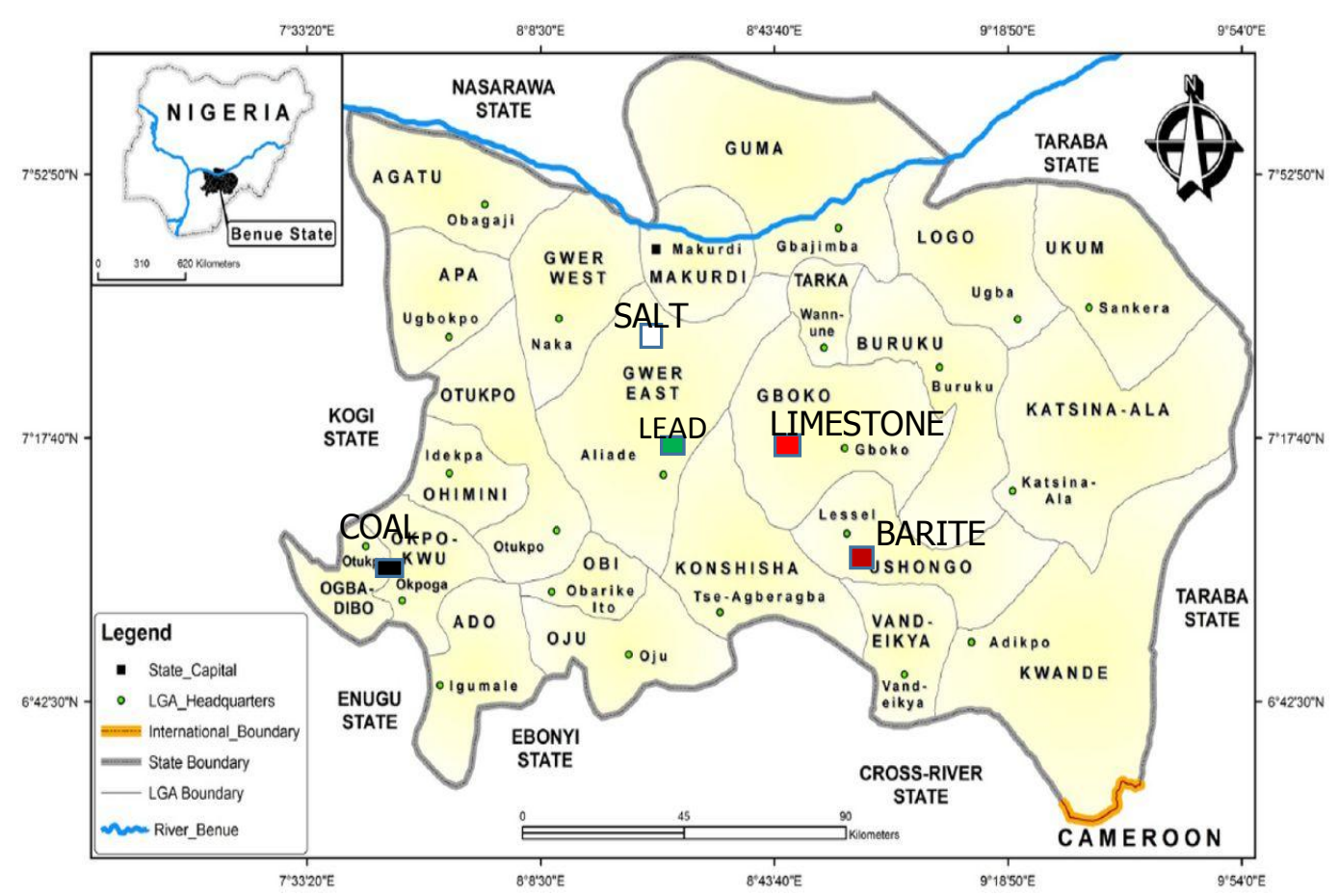

Fig. 1. Map of Benue State, Nigeria, Inset study area

to gamma ray spectroscopy to determine the activities of their constituent radionuclide using sodium iodide detector and counter for 10 hours.

\subsection{Radioactivity Measurement}

The quantitative measurement of natural radioactivity in the soil and minerals samples was done at National Institute of Radiation Protection and Research (NIRP\&R) laboratory, University of Ibadan using a $7.6 \mathrm{~cm} \times 7.6 \mathrm{~cm}$ Thallium Drifted Sodium lodide Nal (TI) detector (Model No 802series) by Canberra Inc. This is coupled to a Canberra series 10 plus Multi-Channel Analyzer (MCA) (Model No 1104) through a preamplifier base. The detector has a resolution of about $8 \%$ at $0.662 \mathrm{MeV}$ energy of ${ }^{137} \mathrm{Cs}$. This gave photo peaks well defined enough to distinguish the gamma-ray energies considered during these measurements. The $1.460 \mathrm{MeV}$ peak was used for ${ }^{40} \mathrm{~K}, 2.615 \mathrm{MeV}$ for ${ }^{232} \mathrm{Th}$, and $1.750 \mathrm{MeV}$ for ${ }^{238} \mathrm{U}$. The calibration of energy of the spectrometer was performed using certified Reference material for radiometric measurement from the International Atomic Energy Agency (IAEA), Vienna. Sources used for energy calibration were ${ }^{22} \mathrm{Na},{ }^{137} \mathrm{Cs},{ }^{60} \mathrm{Co},{ }^{40} \mathrm{~K},{ }^{238} \mathrm{U},{ }^{232} \mathrm{Th}$ emitting gamma rays with energies from 0.511 to $2.615 \mathrm{MeV}$. The detection efficiency calibration of the detector was performed using a reference soil sample, prepared by Rockedyne Laboratories, CA, (No. 48772-356, from Analytic Inc. Atlanta, Georgia (USA)) which is traceable to a mixed standard gamma source. The reference sample has a similar matrix to the soil samples. The source was counted for 36000s and count rate above the background (Cs) for each of the radionuclides was recorded. The efficiencies for each radionuclide were calculated and used to estimate the activity concentration of each of the radionuclide in the samples. The detection efficiency of the system was determined using equation 1 [9]:

$$
\varepsilon_{P}=\frac{c_{S}}{t A_{r} \gamma m}
$$

Where, $C s$ is the net count above the background after counting the reference sample of known Activity $\operatorname{Ar}(\mathrm{Bq} \mathrm{kg})$ and mass $\mathrm{m}(\mathrm{kg})$ for a time $\mathrm{t}$ (s) and $\gamma$ is the gamma ray emission probability.

\section{RESULTS AND DISCUSSION}

\subsection{Activity Concentration of Radionuclides in Raw Minerals and Soil Samples}

The mean activity and the uncertainty level of $\pm S D$ concentrations for radionuclides ${ }^{40} \mathrm{~K},{ }^{238} \mathrm{U}$ 
and ${ }^{232}$ Th with radium equivalent activity values in the minerals and soil samples in the study area are presented in Tables 1 and 2 . The range of values for the three primitive radionuclides are wide, resulting in large values of standard deviations. Based on the measured activity concentration of ${ }^{238} \mathrm{U},{ }^{232} \mathrm{Th}$ and ${ }^{40} \mathrm{~K}$ possible radiation health hazards to the exposed community were evaluated and the results are presented in Table 3 and 4 . Percentage contribution of radionuclides in different soil samples are presented in Fig. 4 (a-d). The interdependency of radiation parameter was carried for all the sample fields based on similarities with respect to distance presented in Figs. 5(a) to (e).

In Table 1 the activity concentrations of ${ }^{40} \mathrm{~K},{ }^{238} \mathrm{U}$ and ${ }^{232} \mathrm{Th}$ in the soil samples varied from
$37.57 \pm 10.94 \mathrm{~Bq} \mathrm{~kg}^{-1}$ (Coal) to $645.52 \pm 184.99 \mathrm{~Bq}$ $\mathrm{kg}^{-1}$ (Lead), 25.15 $\pm 5.56 \mathrm{~Bq} \mathrm{~kg} \mathrm{(Barite)} \mathrm{to}$ 203.95 $\pm 65.12 \mathrm{~Bq} \mathrm{~kg}^{-1}$ (Salt) and $24.81 \pm 5.30$ (Salt) to $53.96 \pm 13.29 \mathrm{~Bq} \mathrm{~kg}^{-1}$ (Barite) respectively. The mean total of the concentration of the radionuclides in the raw minerals is from $B D L$ (Barite and Lead) to $623.36 \pm 158.41 \mathrm{~Bq}$ $\mathrm{kg}^{-1}$ (Salt), $\quad 1.75 \pm 0.10 \mathrm{~Bq} \mathrm{~kg}$ (Lead) to $540.33 \pm 146.43 \mathrm{~Bq} \mathrm{~kg}^{-1}$ (Salt) and BDL (Lead) to $25.28 \pm 2.26 \mathrm{~Bq} \mathrm{~kg}$ (Salt) for ${ }^{40} \mathrm{~K},{ }^{238} \mathrm{U},{ }^{232} \mathrm{Th}$ respectively as shown in Table 2 . Also, the salt mineral samples in this study compared with the work of Tahira and others [10] whose mean activity concentrations of primordial radionuclides in salt samples in Pakistan are 0.5-1.3, 0.4-0.9 and $15.0-34.0 \mathrm{~Bq} / \mathrm{kg}$ respectively, this present study concentrations are quite higher.

Table 1. Specific activity of ${ }^{40} \mathrm{~K},{ }^{238} \mathrm{U}$ and ${ }^{232} \mathrm{Th}$ and radium equivalent activity $(\mathrm{Bq} / \mathrm{Kg})$ in soil samples of different deposition sites

\begin{tabular}{|c|c|c|c|c|}
\hline \multirow[t]{2}{*}{ Area /mineral type } & \multicolumn{3}{|c|}{ Activity concentration IN Bq/kg } & \multirow{2}{*}{$\begin{array}{l}\mathrm{Ra}_{\mathrm{eq}}(\mathrm{Bq} / \mathrm{kg}) \\
\text { Range } \\
\text { Mean }\end{array}$} \\
\hline & $\begin{array}{l}\text { K-40 } \\
\text { Range } \\
\text { (Mean } \pm S D)\end{array}$ & $\begin{array}{l}\text { U-238 } \\
\text { Range } \\
\text { (Mean } \pm S D)\end{array}$ & $\begin{array}{l}\text { Th-232 } \\
\text { Range } \\
\text { (Mean } \pm S D)\end{array}$ & \\
\hline Lessle (Barites) & $\begin{array}{l}129.35-364.56 \\
(237.76 \pm 38.27)\end{array}$ & $\begin{array}{l}12.87-50.97 \\
(25.15 \pm 5.56)\end{array}$ & $\begin{array}{l}24.34-108.41 \\
(53.96 \pm 13.29)\end{array}$ & $\begin{array}{l}60.91-187.40 \\
(120.62)\end{array}$ \\
\hline $\begin{array}{l}\text { Gboko } \\
\text { (Limestone) }\end{array}$ & $\begin{array}{l}160.96-564.93 \\
(333.45 \pm 68.43)\end{array}$ & $\begin{array}{l}26.99-59.51 \\
(42.21 \pm 6.17)\end{array}$ & $\begin{array}{l}25.62-62.73 \\
(42.72 \pm 7.06)\end{array}$ & $\begin{array}{l}86.82-166.24 \\
(128.97)\end{array}$ \\
\hline Anyin & 134.72-1491.47 & 14.88-341.19 & $10.58-49.42$ & 81.89-404.38 \\
\hline $\begin{array}{l}\text { (Lead) } \\
\text { Akuana }\end{array}$ & $\begin{array}{l}(645.52 \pm 184.99) \\
540.37-710.47\end{array}$ & $\begin{array}{l}(87.28 \pm 51.24) \\
42.71-452.32\end{array}$ & $\begin{array}{l}(32.72 \pm 7.19) \\
6.78-35.85\end{array}$ & $\begin{array}{l}(183.78) \\
134.57-515.36\end{array}$ \\
\hline (Salt) & $(632.46 \pm 27.99)$ & $(203.95 \pm 65.12)$ & $(24.81 \pm 5.30)$ & $(288.12)$ \\
\hline $\begin{array}{l}\text { Orokam } \\
\text { (Coal) }\end{array}$ & $\begin{array}{l}11.42-82.06 \\
(37.57 \pm 10.94)\end{array}$ & $\begin{array}{l}19.48-56.81 \\
(36.10 \pm 6.67)\end{array}$ & $\begin{array}{l}18.18-43.82 \\
(27.54 \pm 3.92)\end{array}$ & $\begin{array}{l}48.56-121.45 \\
(78.38)\end{array}$ \\
\hline
\end{tabular}

Table 2. Specific activity of ${ }^{40} \mathrm{~K},{ }^{238} \mathrm{U}$ and ${ }^{232} \mathrm{Th}$ and radium equivalent activity $(\mathrm{Bq} / \mathrm{Kg})$ in mineral samples from different deposit fields

\begin{tabular}{|c|c|c|c|c|}
\hline \multirow{2}{*}{$\begin{array}{l}\text { Mineral } \\
\text { type(s)/code }\end{array}$} & \multicolumn{3}{|c|}{ Activity concentration in $\mathrm{Bq} / \mathbf{k g}$} & \multirow{2}{*}{$\begin{array}{l}\mathrm{Ra}_{\mathrm{eq}}(\mathrm{Bq} / \mathbf{k g}) \\
(\text { Mean } \pm \mathrm{SD})\end{array}$} \\
\hline & $\begin{array}{l}\text { K-40 } \\
\text { (Mean士SD) }\end{array}$ & $\begin{array}{l}\text { U-238 } \\
\text { (Mean士SD) }\end{array}$ & $\begin{array}{l}\text { Th-232 } \\
\text { (Mean士SD) }\end{array}$ & \\
\hline Barites & $\mathrm{BDL}-\mathrm{BDL}$ & $9.04-10.10$ & $2.18-2.08$ & $12.16-13.07$ \\
\hline MBRT (2) & $(-)$ & $(9.57 \pm 0.75)$ & $(2.13 \pm 0.07)$ & $(12.62 \pm 0.64)$ \\
\hline Coal $\mathrm{MCO}(2)$ & $11.08-10.08$ & $1.93-2.01$ & $13.42-12.24$ & $21.97-20.29$ \\
\hline & $(10.58 \pm 0.71)$ & $(1.97 \pm 0.06)$ & $(12.83 \pm 0.83)$ & $(21.13 \pm 1.19)$ \\
\hline Lead MLE(2) & $\begin{array}{l}\text { BDL - BDL } \\
(-)\end{array}$ & $\begin{array}{l}1.82-1.68 \\
(1.75 \pm 0.10)\end{array}$ & $\begin{array}{l}\text { BDL- BDL } \\
(-)\end{array}$ & $\begin{array}{l}1.82-1.68 \\
(1.75 \pm 0.10)\end{array}$ \\
\hline Limestone & $176.26-134.62$ & $12.3-11.32$ & BDL - 12.43 & $25.87-39.46$ \\
\hline MLIM(2) & $(155.44 \pm 29.44)$ & $(11.81 \pm 0.69)$ & $(12.43 \pm 0.0)$ & $(32.67 \pm 9.61)$ \\
\hline Salt MST(2) & $\begin{array}{l}735.37-511.34 \\
(623.36 \pm 158.41)\end{array}$ & $\begin{array}{l}643.87-436.78 \\
(540.33 \pm 146.43)\end{array}$ & $\begin{array}{l}26.88-23.68 \\
(25.28 \pm 2.26)\end{array}$ & $\begin{array}{l}738.93-510.02 \\
(624.48 \pm 161.86)\end{array}$ \\
\hline
\end{tabular}


Table 3. Radiological indices of soil samples from various deposit sites of Benue state

\begin{tabular}{|c|c|c|c|c|c|c|c|}
\hline \multirow[t]{2}{*}{ Sample ID } & \multirow[t]{2}{*}{$D\left(n G y h^{-1}\right)$} & \multirow{2}{*}{$\begin{array}{l}\mathrm{I}_{\mathrm{Y}} \\
\left(\mathrm{BqKg}^{-1}\right)\end{array}$} & \multirow[t]{2}{*}{ AGED (mSv/yr) } & \multirow{2}{*}{$\begin{array}{l}\text { AEDE } \\
\left(\mathrm{mSvyr}^{-1}\right) \\
\text { outdoor }\end{array}$} & \multirow{2}{*}{$\begin{array}{l}\text { ELCR } \\
\left(10^{-3}\right)\end{array}$} & \multicolumn{2}{|c|}{ Hazard indices } \\
\hline & & & & & & $\mathrm{H}_{\mathrm{ex}}$ & $\mathbf{H}_{\text {in }}$ \\
\hline Baryte & & & & $0.03-0.10$ & & & \\
\hline Limestone & 86 & 1.18 & $2 \varepsilon$ & 0.09 & .32 & $\begin{array}{l}0.2 \\
(0 .\end{array}$ & 60 \\
\hline Leac & 37.7 & $.57-2.80$ & $\begin{array}{l}259 . c \\
(609 .\end{array}$ & $0.05-0.23$ & 0.81 & $\begin{array}{l}0.22-1.09 \\
(0.50)\end{array}$ & -2.01 \\
\hline $\mathrm{S}$ & $\begin{array}{l}241.47 \\
4)\end{array}$ & $10-0.30$ & $\begin{array}{l}463.66-1643 \\
(932.48)\end{array}$ & $\begin{array}{l}0.10-0.30 \\
(0.17)\end{array}$ & $\begin{array}{l}0.28-1.04 \\
(0.58)\end{array}$ & $\begin{array}{l}0.36-1.39 \\
(0.78)\end{array}$ & $\begin{array}{l}0.48-2.62 \\
(1.33)\end{array}$ \\
\hline Coal & $\begin{array}{l}21.52-53.77 \\
(34.85)\end{array}$ & $\begin{array}{l}0.34-0.83 \\
(0.54)\end{array}$ & $\begin{array}{l}147.29-366.77 \\
(238.46)\end{array}$ & $\begin{array}{l}0.03-0.07 \\
(0.04)\end{array}$ & $\begin{array}{l}0.09-0.23 \\
(0.15)\end{array}$ & $\begin{array}{l}0.13-0.33 \\
(0.21)\end{array}$ & $\begin{array}{l}0.19-0.48 \\
(0.31)\end{array}$ \\
\hline
\end{tabular}

Table 4. Radiological indices of mineral samples in various deposit sites of Benue State

\begin{tabular}{|c|c|c|c|c|c|c|c|}
\hline \multirow{2}{*}{$\begin{array}{l}\text { Mineral/sample } \\
\text { id }\end{array}$} & \multirow{2}{*}{$\begin{array}{l}\text { D } \\
\left(\text { nGyh }^{-1}\right)\end{array}$} & \multirow{2}{*}{$\begin{array}{l}I_{Y} \\
\left(\mathrm{BqKg}^{-1}\right)\end{array}$} & \multirow{2}{*}{$\begin{array}{l}\text { AGED } \\
\text { (mSv/yr) }\end{array}$} & \multirow{2}{*}{$\begin{array}{l}\text { AEDE } \\
\left(m^{\prime} v_{y r}^{-1}\right) \\
\text { outdoor }\end{array}$} & \multirow[t]{2}{*}{$\operatorname{ELCR}\left(10^{-3}\right)$} & \multicolumn{2}{|c|}{ Hazard indices } \\
\hline & & & & & & $\mathrm{H}_{\mathrm{ex}}$ & $\mathbf{H}_{\text {in }}$ \\
\hline $\begin{array}{l}\text { Barite } \\
\text { MBRT (2) }\end{array}$ & 5.71 & 0.09 & 38.48 & 0.007 & 0.025 & 0.04 & 0.06 \\
\hline $\begin{array}{l}\text { Limestone } \\
\text { MLIM (2) }\end{array}$ & 15.59 & 0.25 & 111.28 & 0.019 & 0.067 & 0.09 & 0.12 \\
\hline $\begin{array}{l}\text { Lead } \\
\text { MLE (2) }\end{array}$ & 0.81 & 0.01 & 5.41 & 0.001 & 0.004 & 0.01 & 0.01 \\
\hline $\begin{array}{l}\text { Salt } \\
\text { MST (2) }\end{array}$ & 290.46 & 4.27 & 1971.01 & 0.357 & 1.247 & 1.69 & 3.15 \\
\hline $\begin{array}{l}\text { Coal } \\
\mathrm{MCO}(2)\end{array}$ & 9.09 & 0.15 & 63.04 & 0.012 & 0.039 & 0.06 & 0.06 \\
\hline
\end{tabular}

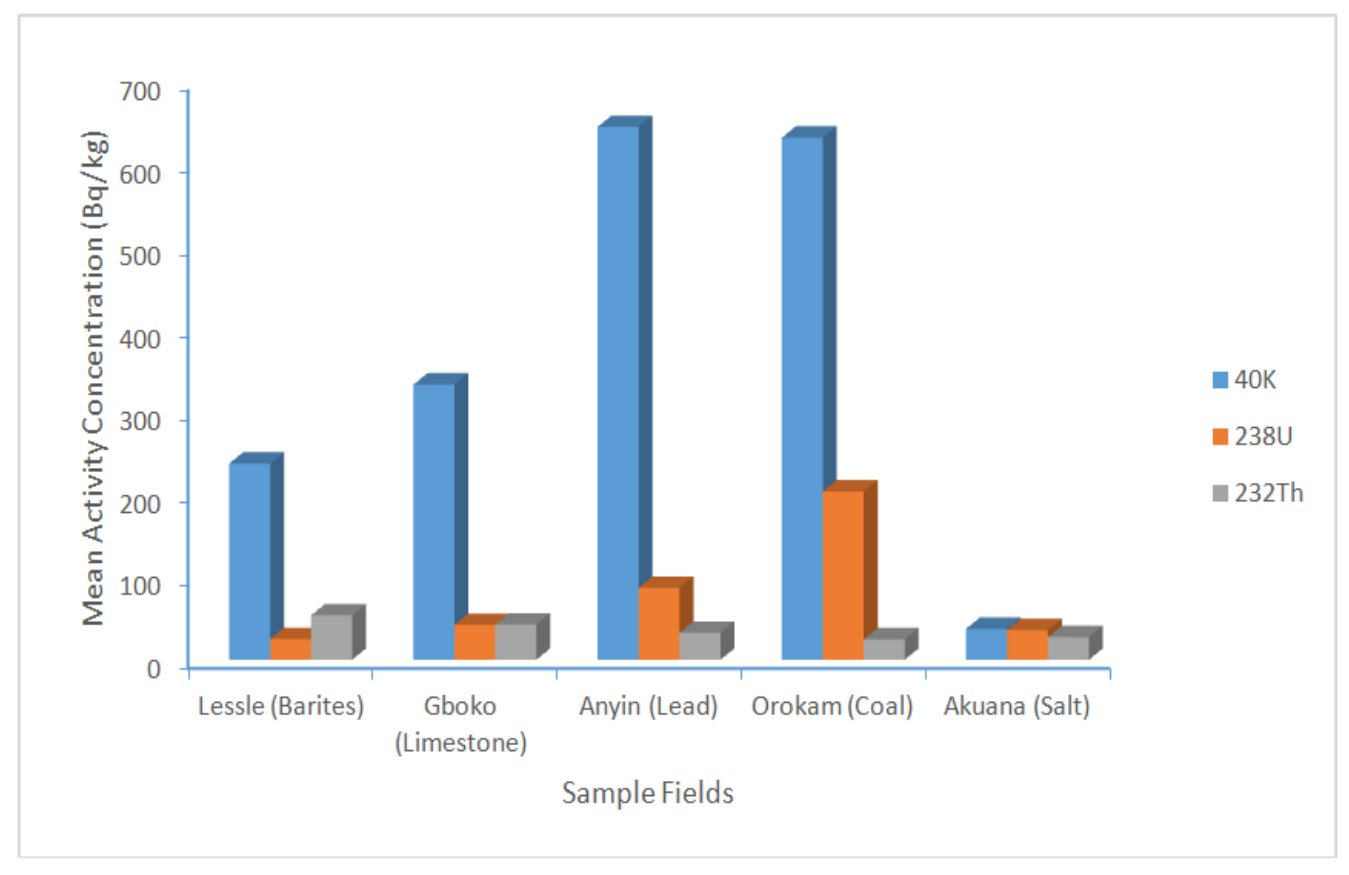

Fig. 2. The mean activity concentration of radionuclides in soil samples (Bq/kg) 


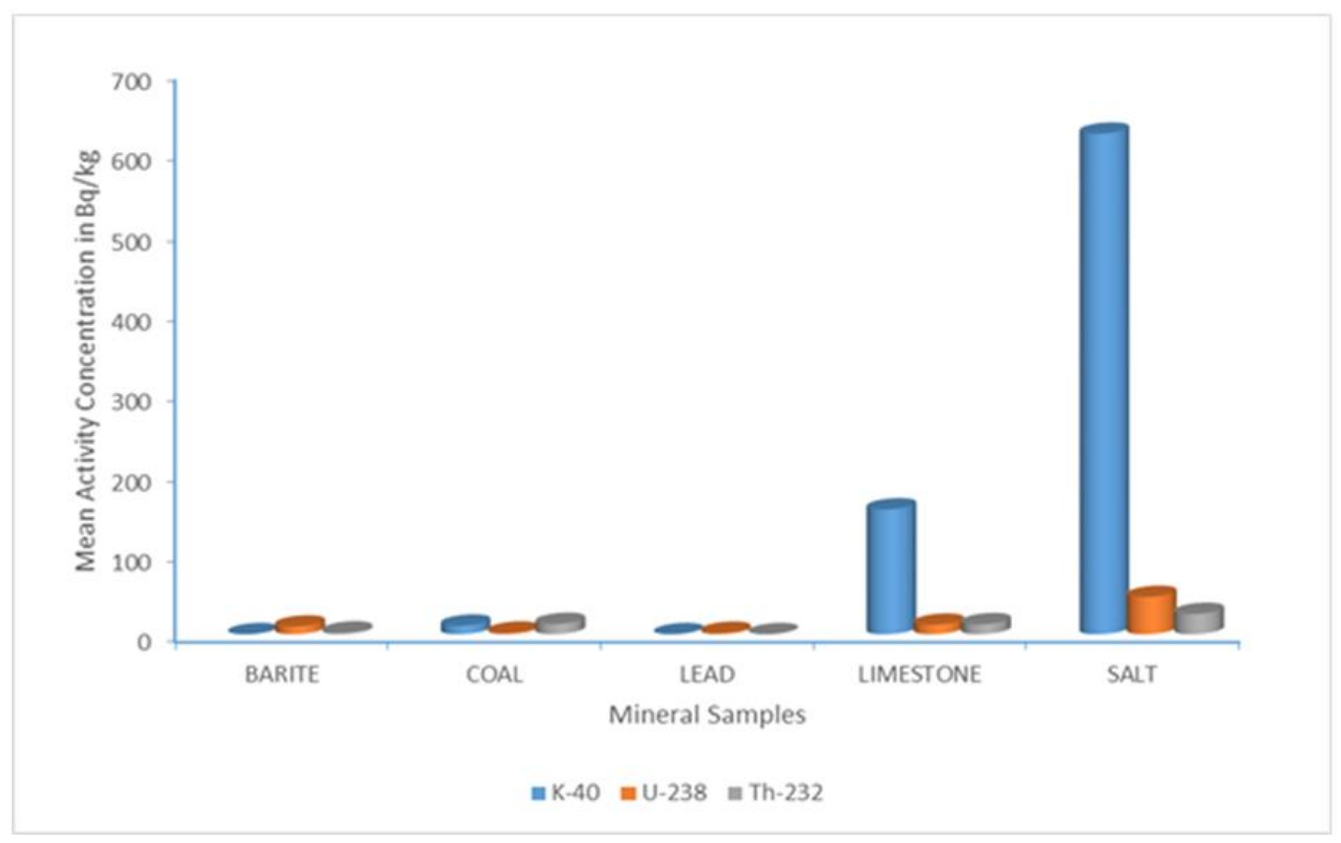

Fig. 3. The mean activity concentration of radionuclides in minerals samples (Bqkg $\left.{ }^{-1}\right)$

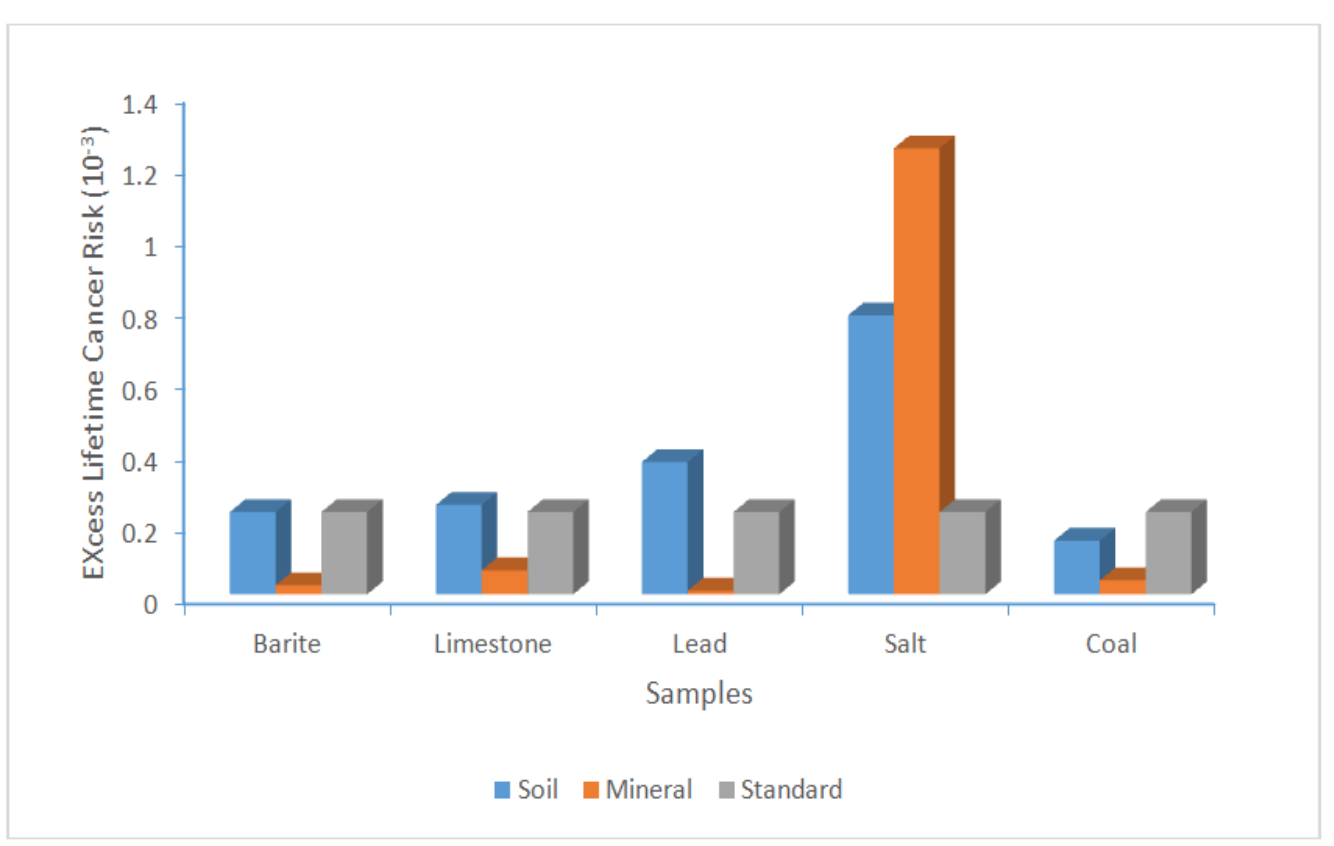

Fig. 4. The mean excess lifetime cancer risk for minerals and soil samples in the mining fields with standard

3.2 Absorbed Dose Rate and Annual the mineral and soil samples base on the [11] Effective Dose Equivalent provision.

The absorbed dose rate and the corresponding annual effective dose equivalent (AEDE) in air at one metre above the ground were estimated for

$$
\begin{aligned}
& D\left(n G y h^{-1}\right)=0.462 C_{R a}+0.621 C_{T h}+ \\
& 0.0417 C_{K}
\end{aligned}
$$


The annual effective dose rate was also estimated using the conversion coefficient from absorbed dose in air to effective dose (0.7 SvGy ${ }^{-1}$ ) and outdoor occupancy factor (0.2) proposed by $[11,12]$. The annual effective dose rate in ( $\left.\mathrm{mSvyr}^{-1}\right)$ was estimated as follows:

$$
\begin{aligned}
& A E D E\left(m S v y r^{-1}\right)=D\left(n G y h^{-1}\right) \times \\
& 0.7 S v G y^{-1} \times 8760 h y r^{-1} \times \frac{10^{3} m S v}{10^{9}} \times 0.2 \\
& A E D E\left(m S v y r^{-1}\right)=D\left(n G y h^{-1}\right) \times 1.2264 \times \\
& 10^{-3}
\end{aligned}
$$

The results of the absorbed dose rates and annual effective dose equivalent for each mining site are presented in Tables 3 and 4 . The absorbed dose rates values in air for the soil and mineral samples ranged from 34.85 (coal) to 135.14 (salt) Gyhr $^{-1} 0.81$ (lead) to 290.46 (salt) nGyhr ${ }^{-1}$, as shown in Table 3.The values obtained for barite, limestone, coal and lead minerals are within the average range of gamma absorbed dose rate in air across Nigerian cities reported $[13,14]$. But the values for soil from these mining fields show a great concern as it's quite higher than the world average value. Samples from salt mining fields have recorded high absorbed dose rate value. The present study values for the mineral samples are within the world's average value of $55 \mathrm{nGy} / \mathrm{hr}$ [11] and the maximum value obtained for salt is higher than the standard.

\subsection{Radiation Hazard Indices}

The basic radiological parameters such as Radium equivalent activity $\left(\mathrm{Ra} \mathrm{eq}_{\mathrm{eq}}\right)$, external hazard index $\left(\mathrm{H}_{\text {ex }}\right)$ and internal hazard index $\left(\mathrm{H}_{\text {in }}\right)$ and gamma activity index $\left(I_{\gamma r}\right)$ for the soils and minerals were estimated in order to ascertain the suitability of the raw minerals for use as building materials.

\subsubsection{Radium equivalent activity $\left(\mathrm{Ra}{ }_{\mathrm{eq}}\right)$}

In order to represent the activity levels of ${ }^{226} R a$ $\left({ }^{238} \mathrm{U}\right),{ }^{232} \mathrm{Th}$ and ${ }^{40} \mathrm{~K}$ by a single quantity, a common radiological index has been introduced which takes into amount the radiation hazards associated with them. This index is called Radium equivalent $\left(\mathrm{Ra}_{\mathrm{eq}}\right)$. The radium equivalent activity is mathematically defined [11].

$$
R a_{e q}\left(B q k g^{-1}\right)=C_{R a}+1.43 C_{T h}+0.077 C_{K}
$$

Where, is the activity concentration of ${ }^{238} \mathrm{U}, C_{T h}$ is the activity concentration of ${ }^{232} \mathrm{Th}$, and $C_{K}$ that of ${ }^{40} K$.

The evaluated values of the radium equivalent activity $\left(\mathrm{Ra}_{\mathrm{eq}}\right)$ for the five minerals samples ranged from $1.75 \pm 0.10 \mathrm{~Bq} / \mathrm{kg}$ (Lead) to $624.48 \pm 161.86 \mathrm{~Bq} / \mathrm{kg}$ (Salt) in Table 1 while the soil samples $\mathrm{Ra}_{\mathrm{eq}}$ ranged from $78.38 \mathrm{~Bq} / \mathrm{kg}$ (Coal) to $288.12 \mathrm{~Bq} / \mathrm{kg}$ (Salt). The radium equivalent dose rate $\left(\mathrm{Ra}_{\mathrm{eq}}\right)$ obtained for Barites, Limestone, Coal and Lead were within range reported [15] for minerals samples while the salt mineral samples higher than the result reported. The maximum estimated values of radium equivalent activity due to ${ }^{40} \mathrm{~K},{ }^{238} \mathrm{U}$ and ${ }^{232} \mathrm{Th}$ in the minerals is $624.48 \mathrm{~Bq} / \mathrm{kg}$ in soil samples which is nearly double the permissible value of $370 \mathrm{~Bq} / \mathrm{kg}$ [16]. The higher value obtained in salt minerals and soils of the mining fields may be as a function of the geographical location and the overlying or underlying surrounding geological material structure of the salt mine fields.

\subsubsection{External hazard index $\left(\mathrm{H}_{\mathrm{ex}}\right)$, and Internal hazard index $\left(\mathrm{H}_{\mathrm{in}}\right.$ ), gamma activity index $\left(I_{\gamma r}\right)$ and excess lifetime cancer risk (ELCR)}

The widely used hazard index revealing the external exposure is the external hazard index $\mathrm{H}_{\text {ex }}$ and is defined by equation $5[17,11]$.

$$
H_{e x}=370 C_{R a}+259 C_{T h}+4810 C_{K}
$$

In addition to the external hazard index, Radon and its short-lived products are also hazardous to the respiratory organ, the internal exposure to radon and its daughters is quantified by the internal hazard index $\mathrm{H}_{\text {in }}$, given by equation (6) [18].

$$
H_{\text {in }}=185 C_{R a}+259 C_{T h}+4810 C_{K}
$$

Where, $C_{R a}, C_{T h}$, and $C_{K}$ are the activity concentrations of Uranium, Thorium and Potassium.

The gamma activity concentration index $\left(I_{\gamma r}\right)$ representative level index is also estimated to correlate with the annual effective dose equivalent due to the excess external gamma radiation caused by superficial material. It is defined using equation (7), proposed by [19]; 


$$
I_{\gamma r}=150 C_{R a}+100 C_{T h}+1500 C_{K}
$$

Values of index $I \gamma r \leq 1$ corresponds to $0.3 \mathrm{mSv}$ $y r-1$, while $I \gamma r \leq 3$ corresponds to $1 \mathrm{mSvyr}^{-1}$.

The results obtained in this work for the external and internal hazard indices and the gamma activity index are presented in Table 3.

The annual effective dose calculated was used to estimate the excess lifetime cancer risk (ELCR) is calculated using equation (8).

$$
\begin{aligned}
& E L C R=A E D E \times \text { Average duration of life } \\
& (D L) \times \text { Risk factor }(R F)
\end{aligned}
$$

Where AEDE, DL and RF is the annual effective dose equivalent, duration of life (70 years) and risk factor (Sv-1), fatal cancer risk per sievert. For low dose background radiations which are considered to produce stochastic effects, ICRP 60 uses values of 0.05 for the public [20].

The annual effective dose equivalent (AEDE), gamma index $\left(\mathrm{I}_{\mathrm{Y}}\right)$, Annual gonadal equivalent dose (AGED) calculated ranges from 0.001 (lead) to 0.357 (salt) $\mathrm{mSv} / \mathrm{yr}, 0.01$ (lead) to 4.27 (salt) $\mathrm{Bq} / \mathrm{kg}$ and 5.41 (lead) to 1971.01 (salt) $\mathrm{Bq} / \mathrm{kg}$ respectively.

The values of the external hazard index $\left(\mathrm{H}_{\text {ex }}\right)$ are also shown in Table 4 for the minerals considered in this study. The highest value obtained is 1.69 for salt while the lowest value is 0.01 for Lead. The values of the $\mathrm{H}_{\text {ex }}$ estimated in this study are less than unity, and as such, none of the minerals considered in this study are a major source of external radiation exposure.

In addition to the external hazard, radon and its short-lived products can also posed a hazard to the respiratory organs. The internal exposure to radon and its progenies is computed by the internal hazard index $\left(\mathrm{H}_{\text {in }}\right)$. If the maximum concentration of radium is half that of the normal acceptable limit, then $\mathrm{H}_{\text {in }}$ will be less than 1 [21]. The calculated values of $\mathrm{H}_{\text {in }}$ in this study for the minerals ranged from 0.103 to 0.356 . These values are not up to half of a unit.

The results obtained in all the mineral mining field for gamma index, external hazard index $\left(\mathrm{H}_{\text {ex }}\right)$, internal hazard index $\left(\mathrm{H}_{\text {in }}\right)$ and annual gonadal dose are less unity and $300 \mathrm{mSv} / \mathrm{yr}$ except salt mining fields. The annual effective dose equivalent estimated in all the mining field for minerals are well below the world's average value $0.48 \mathrm{mSv} / \mathrm{yr}$ [22].

The excess lifetime cancer risk (ELCR) calculated as could be seen Table 3 ranges from 0.15 (Coal) to 0.58 (Salt) for soil samples and 0.004 (Coal) to 1.247 (Salt) for mineral samples. Although the ELCR of soil sample Limestone, Lead and Salt mining fields has mean values which are higher than the world average value of $0.23 \times 10^{-3}$ as shown in Fig. 4 but the mean ELCR of soil sample Coal and Barite mining fields is close to the world average value. The ELCR of sample Limestone, Lead, Coal and Barite has mean values which are less than the world average value but since the mean ELCR of Salt is greater than the world average value, the minerals may pose major radiological risk to the inhabitants of buildings and external exposure from materials used in the homes that are end products of these minerals.

\subsection{Percentage Contribution of Radionuclides in Different Soil Samples}

Fig. 4 (a) to (e), show percent distribution of the three radionuclides in soil samples collected from background locations in Barites field, limestone pit, lead deposit area, Salt/Brine field and Coal/Anthracite field. The distribution in background soil within the limestone mining field and lead mining field ${ }^{40} K(80-84 \%)$ followed by ${ }^{238} \mathrm{U}$ and ${ }^{232} \mathrm{Th}$ respectively. ${ }^{232} \mathrm{Th}$ had the minimum share in major mining field soil samples while ${ }^{238} U$ had minimum share in Barite soil samples. This result is constant with the mean activities of these radionuclides in the crust of the earth, showing no contamination of the field deposits activities and the surrounding area by the anthropogenic activities in the mining fields.

The distribution percent in soil from the limestone field was least dominated by ${ }^{238} U$ and ${ }^{232} \mathrm{Th}$ with both contributing $10 \%$ each. This shows that the soil at limestone field contains large amounts of rock phosphate, and thus both ${ }^{238} U$ and ${ }^{232} \mathrm{Th}$ are in secular equilibrium as is the case in most of the mineral deposits.

The soil from coal and salt field showed maximum contribution from ${ }^{40} K$ followed by ${ }^{238} U$. As the thorium concentrations are reduced greatly in the coal deposits field, ${ }^{232} \mathrm{Th}$ shared nearly half of the percentage of that of ${ }^{40} \mathrm{~K}$ and ${ }^{238} U$ in the coal deposit soil. 
The soil from barite mining field showed minimum contribution $8 \%$ from ${ }^{238} U$ compared to other mineral mining fields with slightly higher percent of $17 \% \mathrm{in}^{232} \mathrm{Th}$.

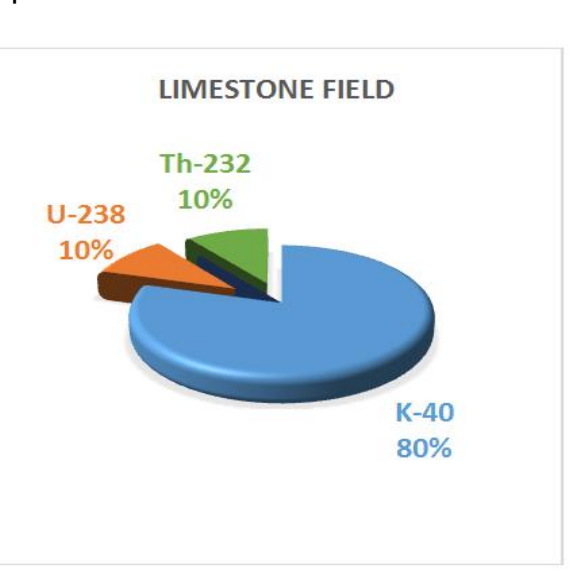

(b)

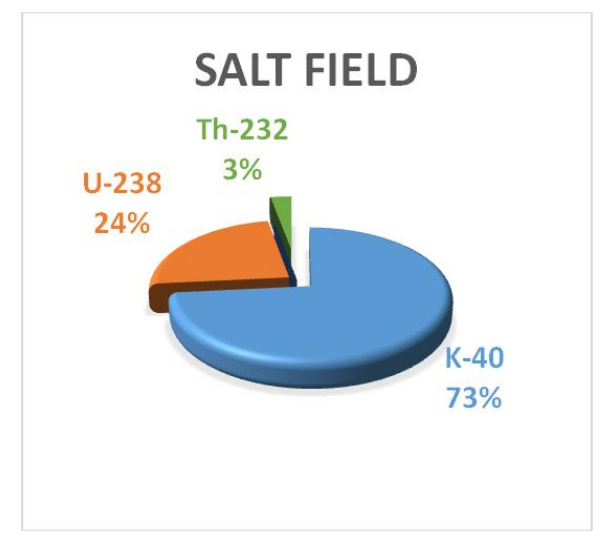

(c)

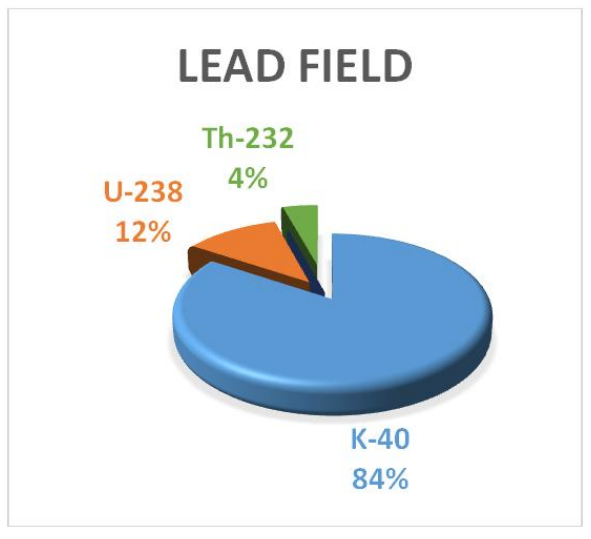

(d)

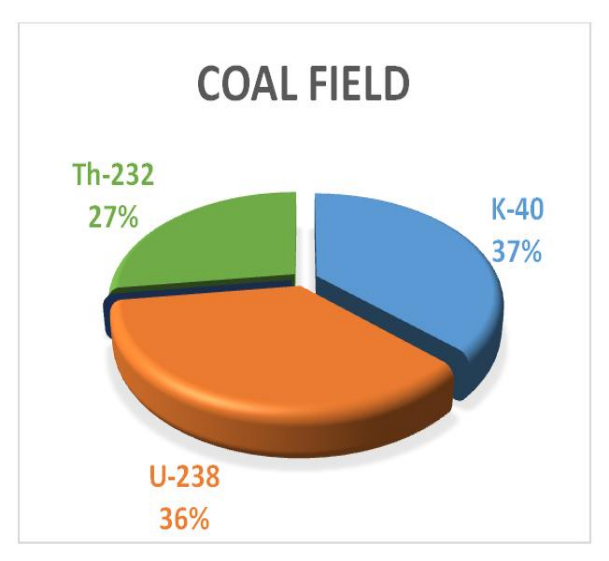

(e)

Fig. 4(a-e). Percentage contribution of radionuclides in each mine field in soil samples 


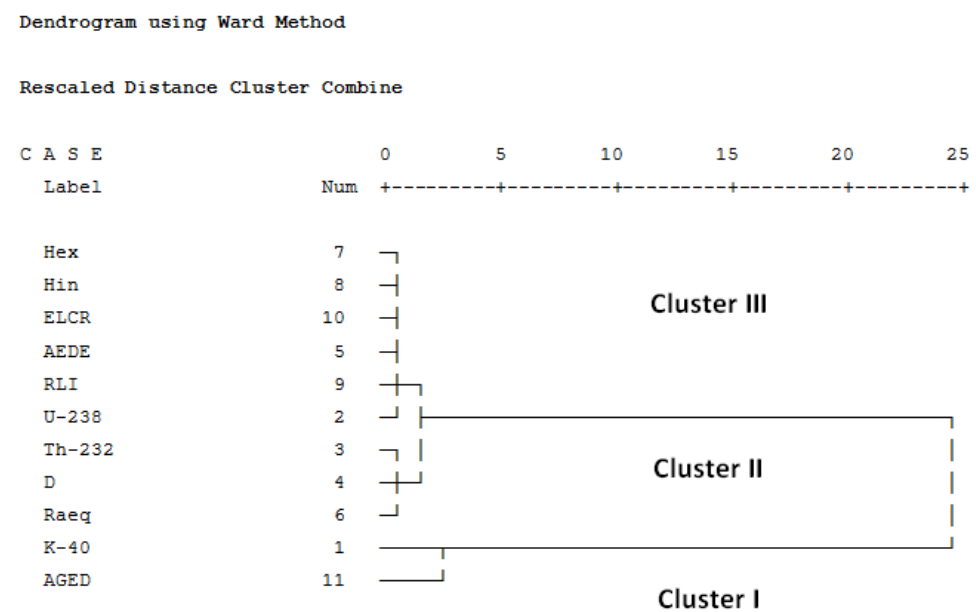

Fig. 5a. Clustering of radioactive variables in soil samples of barites mine field Dendrogram using ward Method Rescaled Distance Cluster Combine

C A S E
Labe1
Hex
ELCR
Hin
AEDE
RLI
U-238
Th-232
D
Raeq
K-40
AGED

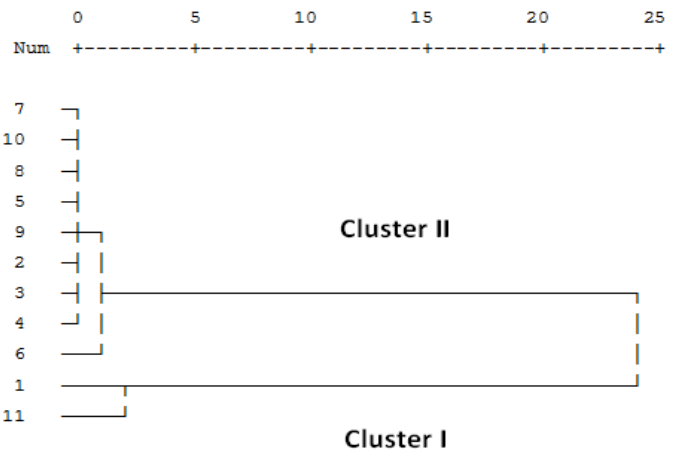

Fig. 5b. Clustering of radioactive variables in soil samples of limestone mine field

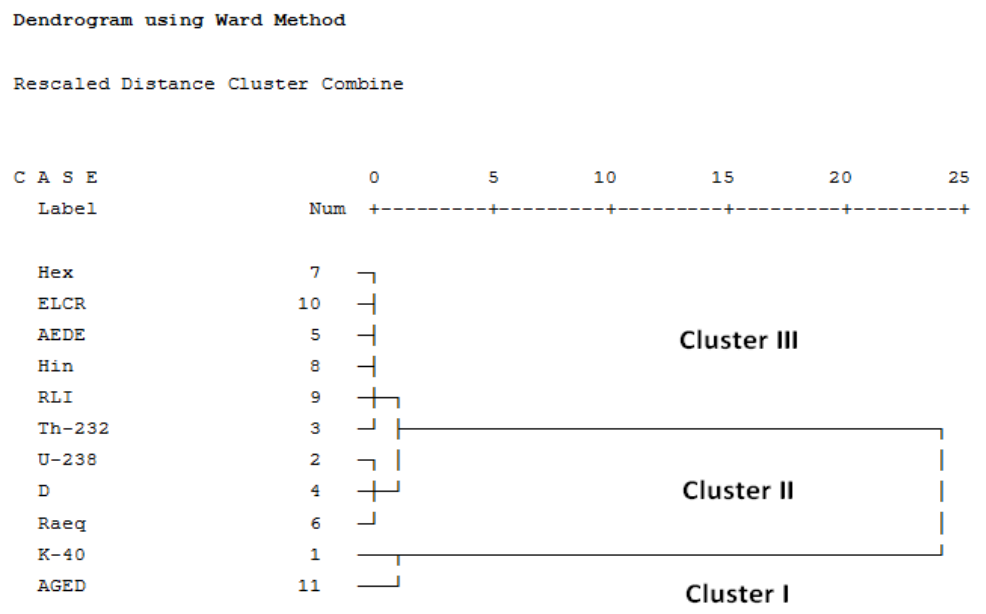

Fig. 5c. Clustering of radioactive variables in soil samples of lead mine field 


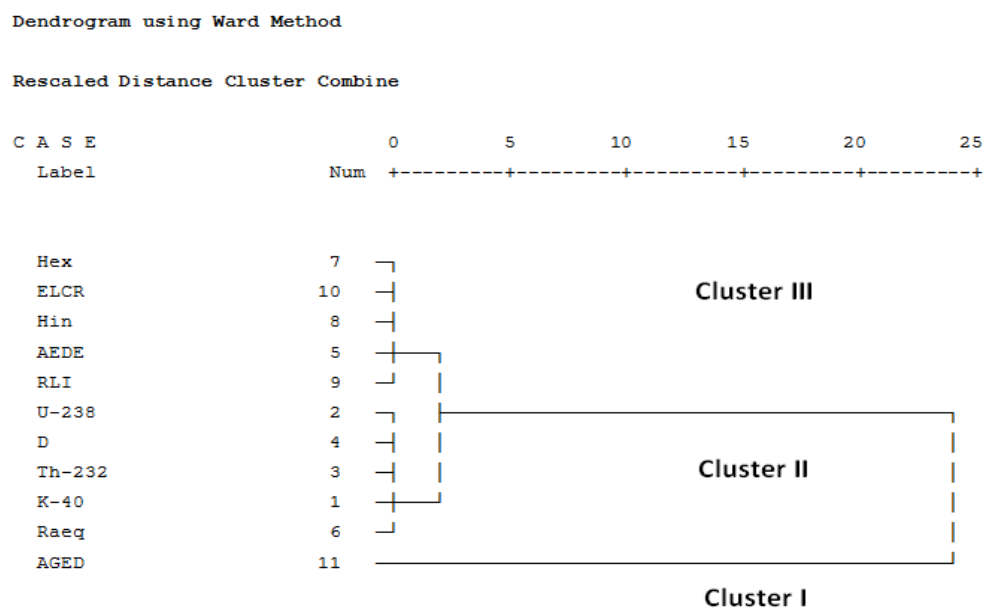

Fig. 5 d. Clustering of radioactive variables in soil samples of coal mine field

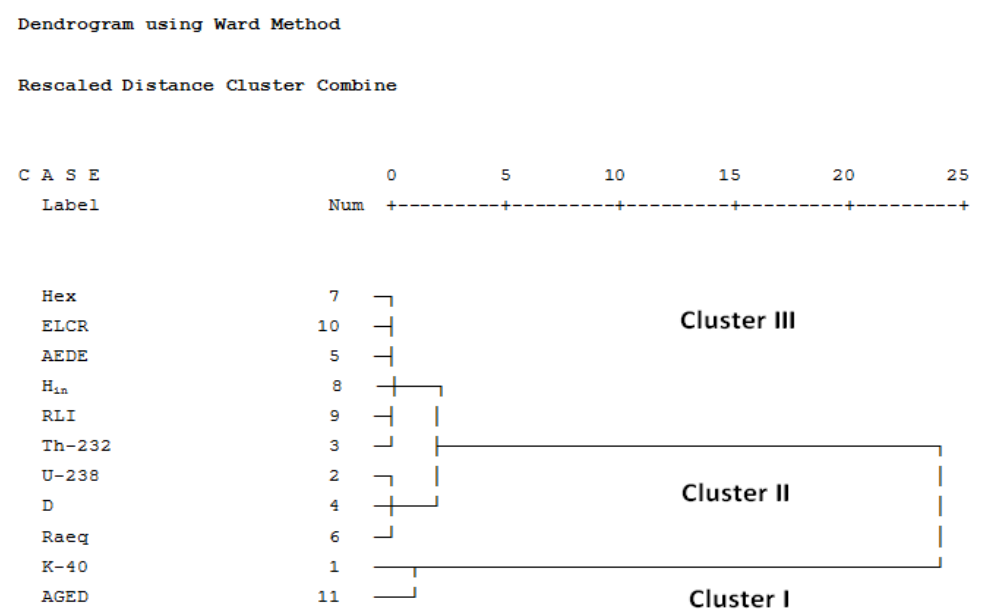

Fig. 5e. Clustering of radioactive variables in soil samples of salt mine field

\subsection{Cluster Analysis}

The results of analysis about the grouping of variables in the basis of similarity of the measured radionuclides are presented in Figs. 5 (a) to (e).

Dendrogram in Figs. 5(a, c, d and e), have variables grouped into three statistical clusters based on the similarity of the variables except Fig. $5 \mathrm{~b}$ which have two statistical clusters. Clusters I consists of two variables such as ${ }^{40} \mathrm{~K}$ and AGED. In this cluster, ${ }^{40} K$ is only the radioactive variables with comparatively high similarities with AGED as shown in Fig. 5(a). Cluster I confirms that the radioactivity variables AGED except ${ }^{238} U$ and ${ }^{232} \mathrm{Th}$ mainly depend upon the potassium ${ }^{40} K$ constituent/content.
${ }^{232} \mathrm{Th}$ is a radioactive variables with comparatively high similarities with $D$ and $\mathrm{Ra}_{\mathrm{eq}}$. This implies that $D$ and $R a_{\text {eq }}$ are rich in ${ }^{232} T h$. Cluster II is also linked with cluster III variables with low similarity. However ${ }^{232} \mathrm{Th}$ has similarities to AGED. Uranium constituent in cluster III is an affirmation of radioactive variables present are liable of inducing some of level of radioactivity. Dendrogram for limestone mine samples is similar to that barite field soil samples which consists of two variables $\left({ }^{40} K\right.$ and AGED) as shown in Fig. 5(b). The dendrogram shows that ${ }^{238} \mathrm{U}$ and ${ }^{232} \mathrm{Th}$ are comparatively of high similarities with radiological hazard indices liable to spur cancer while ${ }^{40} K$ with high similarities comparatively with AGED, this is liable to induce some radioactive levels on sensitive parts of human body such bone marrow and bone 
surface cells. The dendrogram in Fig. 5(c) represent Lead mine samples, in these clusters, ${ }^{40} K$ is comparatively of high similarities with $\mathrm{Ra}_{\mathrm{eq}}$ and AGED. Cluster I is linked with clusters II and III with high similarities with cluster II of extremely low similarities with cluster III. The dendrogram grouping shows a spread out of the main radioactive variables. Thus, the clusters should be a factor to induce different level of radioactivity. Dendrogram for coal mine sample shows Cluster I contain AGED only its group in Fig. $5 \mathrm{~d}$. This cluster is also linked with cluster II and III with very low similarity. Radiation hazard will be uniformly distributed since all major radiation variables are present in such samples. Dendrogram for salt mine samples as could be seen Fig. $5 e$. The clusters grouping is similar to lead mine field dendrogram. Cluster I consists of two variable ${ }^{40} \mathrm{~K}$ and AGED, Cluster II consists of three variables ${ }^{238} U, \mathrm{D}$ and $\mathrm{Ra}_{\text {eq }}$ and Cluster III consists of six variables ${ }^{232} \mathrm{Th}, \mathrm{RLI}, \mathrm{H}_{\text {in }}, \mathrm{AEDE}$, ELCR and $H_{e x}$ respectively. Cluster I and cluster II are comparatively low similarities while cluster II and cluster III are of high similarities. Composition of each clusters contains main variables, which implies that radiation effects are liable to occur in the indices estimated.

\section{CONCLUSION}

Quantification of the activity concentrations of ${ }^{40},{ }^{238} \mathrm{U}$ and ${ }^{232} \mathrm{Th}$ in minerals and soil samples around some mining sites have been carried out in this work and the resulting hazard indices and the absorbed dose in air have been estimated. No anthropogenic radionuclide was detected in any of the samples.

1. The distribution in background soil within the limestone mining field and lead mining field for ${ }^{40} K$ (80-84\%) followed by ${ }^{238} U$ and ${ }^{232} \mathrm{Th}$ respectively. ${ }^{232} \mathrm{Th}$ had the minimum share in major mining field soil samples while ${ }^{238} U$ had minimum share in Barite mining field soil samples.

2. The activity concentration of ${ }^{238} U,{ }^{232} T h$ and ${ }^{40} \mathrm{~K}$ in all the samples in all the mineral mining fields were within safe limits except in salt mining fields

3. The mean absorbed dose rate in minerals (Salts mining fields) field and soil (Limestone and Lead mining fields) are higher than the world average UNSCEAR acceptable value.
4. The AEDE, AGED and $\mathrm{Ra}_{\text {eq }}$ calculated in the soil and mineral samples in barite and coal mining fields are within the safe limit.

5. Radiation hazard Indices calculated in all the samples are < 1 except in salt mine field

6. The ELCR calculated in the soil and mineral samples in barite, limestone and coal mine fields are within the safe limit but quite high in lead and salt mine fields.

7. This shows that there has not been any radioactive contaminant in the mining sites studied.

8. The low values of radiological hazard indices in mineral mining fields show that the minerals are safe for use as building and construction materials and any other use of such in dwellings in the study area.

\section{COMPETING INTERESTS}

Authors have declared that no competing interests exist.

\section{REFERENCES}

1. Mahtani D. The new scramble for Africa's resources. Financial Times Special Report. 2008;1-6.

2. MMSD. Ministry of mines and steel development. Barytes, Exploration in Nigeria; 2010.

3. Chang BU, Koh SM, Kim YJ, Seo JS, Yoon YY, Row JW, Lee DM. Nationwide survey on the natural radionuclides in industrial raw materials in South Korea. Journal of Environmental Radioactivity. 2008;99:455460.

4. Habshi F. The recovery of uranium from phosphate rock: Progress and problems, proceeding of the $2^{\text {nd }}$ international congress on phosphorus compounds. Institute Mondial du Phosphate, Paris. 1980;629-660.

5. Kogbe CA, Torkeshi A, Osiyuk D, Wozney DE. Geology of Makurdi sheet 257 the middle Valley, Nigeria. Occasional Publication, Dept. of Geology, Ahmadu Bello University. Zaria; 1978.

6. Abaa SI. Origin of the Benue trough and its economic significance to Nigeria. Being the $2^{\text {nd }}$ Inaugural lecture of Benue State University, Makurdi, Nigeria; 2004.

7. Benue State ministry of environment and solid mineral development. Benue State 
investment potentials in solid minerals. Government Bulletin. 2006;5.

8. Gilmore G, Hemingway JD. Practical gamma spectrometry. John Wiley and Sons, NY; 1995.

9. Farai IP, Okwunakwe CE, Makinde OS. Gamma spectroscopic assay of soil samples from waste dumps sites in PortHartcourt Nigeria presented at ICMR conference. September 3-7. Cape Town, South Africa; 2007.

10. Tahir SNA. Alaamer AS. Determination of natural radioactivity in rock salt and radiation doses due to its ingestion. Journal of Radiological Protection. 2008; 28:233-236.

11. UNSCEAR. Sources, effects and risks of ionizing radiation, United Nations Scientific Committee in effects of Atomic Radiation Report to the General Assembly, with Annexes, New York; 2000.

12. Arafa W. Specific activity and hazards of granite samples collected from the eastern desert of Egypt. Journal of Environmental Radioactivity. 2004;73:315-327.

13. Obed RI, Farai IP, Jibiri NN. Population dose distribution due to soil radioactivity concentration levels in 18 cities across Nigeria. J Radiol Prot. 2005;25:305-312.

14. Farai IP, Jibiri NN. Baselines of terrestrial outdoor gamma dose rate levels, in Nigeria. Radiation protection Dosimetry. 2000;88(3):247-254.

15. Jibiri NN, Temaugee ST. Radionuclide contents in raw minerals and soil samples and the associated radiological risk from some mining sites in Benue State NorthCentral Nigeria. International Journal of
Scientific \& Engineering Research. 2013; 4(7):2392.

ISSN: $2229-5518$

16. United Nations Scientific Committee for effects of atomic radiation. Ionizing radiation: Sources and Effects. 1988;4489.

17. Beretka J, Matthew PJ. Natural radioactivity of Australian building materials, industrial waste and byproducts. Health Physics. 1985;48:87-95.

18. Abel-Ghany HA, El-Zakla T, Hassan AM. Environmental radioactivity measurement of some Egyptian sand samples. Rom. Journ. Phys. Bucharest. 2009;54(1-2):213223.

19. EC (European Commission). Report on radiological protection principles concerning the natural radioactivity of building materials. Radiation Protection. 1999;112.

20. Taskin H, Karavus M, Ay P, Topozoglu A, Hindiroglu S, Karahan G. Radionuclide concentrations in soil and life time cancer risk due to gamma radioactivity in Kirklareli, Turkey. Journal of Environmental Radioactivity. 2009;100:49-53.

21. Ferdoes S, Al-Salel, Badriah Al-Berzan. Measurements of natural radioactivity in some kind of marble and granite used in Riyadh region. Journal of Nuclear and radiation Physics. 2007;2(1)25-36.

22. UNSCEAR (United Nations Scientific Committee on the effects of atomic radiation). Sources and effects of ionizing radiation, Report to the general assembly with scientific annexes. United Nations, New York; 1993.

(c) 2017 Olanrewaju and Avwiri; This is an Open Access article distributed under the terms of the Creative Commons Attribution License (http://creativecommons.org/licenses/by/4.0), which permits unrestricted use, distribution, and reproduction in any medium, provided the original work is properly cited.

Peer-review history:

The peer review history for this paper can be accessed here: http://sciencedomain.org/review-history/19360 